\title{
Andrzej Leder, Rysa na tafli. Teoria w polu psychoanalitycznym, PWN, Warszawa 2016, ss. 362
}

DOI: http://dx.doi.org/10.12775/RF.2018.019

Andrzej Leder jest profesorem filozofii w Instytucie Filozofii i Socjologii Polskiej Akademii Nauk. Jego wcześniejszą książkę zatytułowaną Prześniona rewolucja nominowano do Literackiej Nagrody NIKE 2015. We wspomnianej monografii Leder korzystał z kategorii psychoanalitycznych, które miały pomóc w opisie najnowszych dziejów Polski. Główne dzieła Andrzeja Ledera to: Nieświadomość jako pustka i Przemiana mitów, czyli życie w epoce schyłków. Interesujący wydaje się fakt, że Leder jest także czynnym psychoterapeutą.

W monografii Rysa na tafli. Teoria w polu psychoanalitycznym została zastosowana "teoria pola psychoanalitycznego", która dotyczy teoretycznych wypowiedzi analizowanych dzięki kategoriom pochodzącym z psychoanalizy w odniesieniu do badań historycznych i filozoficznych ${ }^{1}$. Autor publikacji za koniec dwudziestego wieku uważa wydarzenie z 11 września 2001 roku w Stanach Zjednoczonych, kiedy to doszło do tragicznego w skutkach ataku terrorystycznego na World Trade Center. W odniesieniu do sytuacji historycznych i traumatycznych Leder wprowadza triadę tego, co symboliczne, wyobrażeniowe i realne, pochodzącą z rozważań francuskiego psychoanalityka Jacques'a Lacana. Wy obrażeni owe związane jest z obrazowaniem, naocznością, bezpośrednią intuicją sensów, a także z tym, że wpływa na rozwój myśli. Symboliczne odwołuje się do dynamicznego ruchu ludzkiej myśli w przestrzeni językowej, dzięki czemu może nastąpić zmiana sensu zdania, a zatem interpretacji wydarzenia historycznego, bardzo ważne są tutaj pojęcia przemieszczenia i kondensacji. Realne natomiast ma zaburzać ruch w sferze symbolicznej. Obecność tego, co realne jest zarazem negatywna i niszcząca ${ }^{2}$. W XX stuleciu istotne wydarzenia poskutkowały przeżyciem głębokiej traumy. „Trauma to przecież „,stan

\footnotetext{
1 A. Leder, Rysa na tafli. Teoria w polu psychoanalitycznym, Warszawa 2016, s. 12.

2 Ibidem, s. 13.
} 
wyjątkowy" duszy. Zaprzecza porządkowi symbolicznemu, unicestwia czas i mediację. Dopiero żałoba jest wyznaczeniem miary traumie"3.

Leder jako filozof kultury sądzi, że problematyka traumy i samych wydarzeń traumatyzujących wywodzi się ze stolicy Niemiec - Berlina. To właśnie tam zaczęła się groza teoretycznych systemów i myśli. Niemiecka filozof Hannah Arendt stwierdziła, że w Niemczech następuje epoka schyłkowa, którą przyobleka „czarny duch nudy”4. Walter Benjamin w swym Berlińskim dzieciństwie na przełomie wieków przypisuje jej charakter depresyjny i melancholijny. Również Eric Auerbach niemiecko-żydowski krytyk literacki oraz autor Mimesis. Rzeczywistość przedstawiona w literaturze Zachodu dostrzegł rozpad świata i brak zainteresowania tym, co antropologiczno-humanistyczne. To wówczas pojawiła się nuda, zakwestionowanie tego, co może przywrócić człowieczeństwo, a nastąpiła dominacja złośliwej agresji i triumf Freudowskiego Tanatosa, czyli instynktu śmierci ${ }^{5}$. Czechosłowacki filozof Jan Patočka ${ }^{6}$ wychodzi z założenia, że cały XX wiek jest stuleciem wojny. Dwudzieste stulecie przesiąknięte jest absolutną bezpośredniością przeżywania i doświadczania śmierci oraz okrucieństwa w sensie nie tyle antropologicznym, ile również estetycznym. Patočka odwołuje się do doświadczenia frontowego, które "dopadło" Czechosłowację po stłumieniu buntów przez wojska Układu Warszawskiego w sierpniu 1968 roku. Spokój i harmonia dnia zostały zanegowane przez opór barbarzyńskiej nocy ${ }^{7}$.

Niegodziwość, biurokracja, a przede wszystkim pożądanie krwi i zniszczenia cechowały zmagania frontowe I wojny światowej. Leder stwierdza, że z jednej strony Wielka Wojna stanowiła zderzenie emancypującego się ludu, a z drugiej chęci zatrzymania tradycyjnej hierarchii społecznej ${ }^{8}$. Żołnierze walczący po obu stronach konfliktu wierzyli w stałe normy moralne nakazujące walczyć w poczuciu obowiązku. Nowożytna Europa wypracowała system symboliczny, strukturę światopoglądową i przekonania, które okazywały stronom walczącym silny fundament etyczny i osobowościowy, lecz żołnierze samotnie karmili się jedynie własną wyobraźnia, własnym poczuciem estetyki, rozsądek stał się bowiem kluczową ofiarą wojny. Ofiarami okazali się również

3 Ibidem, s. 20.

4 Ibidem, s. 25. Zob. H. Arendt, Korzenie totalitaryzmu, przeł. D. Grinberg, M. Szawiel, Warszawa 2014, s. 58.

5 Ibidem, s. 30.

6 Wart podkreślenia jest fakt, że Patočka należał do grona rzeczników i intelektualistów Karty 77, znanego manifestu dotyczącego obrony praw człowieka i wprowadzenia systemu demokratycznego w Czechosłowacji.

7 A. Leder, Rysa na tafli. Teoria w polu psychoanalitycznym, s. 39.

8 Ibidem, s. 52. 
ludzie, nieprzerwanie znikający w mrokach min i zanieczyszczonego, spalonego nieba9.

Autor publikacji uważa, że winnym takiego stanu rzeczy była przede wszystkim metafizyka. Niemiecka narodowa tożsamość powstawała dzięki idealistycznym systemom takich filozofów, jak: Johann Gottlieb Fichte i Georg Wilhelm Friedrich Hegel. Nowoczesna tożsamość związana była także z rozwojem romantyzmu, który przeciwstawiał się założeniom oświeceniowym. Ważna wydawała się także filozofia życia: Wilhelma Diltheya, Georga Simmela, Friedricha Nietzschego i Oswalda Spenglera ${ }^{10}$. Do „wybuchu” dwudziestowiecznych wojen przyczyniły się przede wszystkim teorie zawierające model rozszczepionego ",ja", doprowadzający do stworzenia nieludzkich konstruktów Alfreda Rosenberga czy Nadieżdy Krupskiej, które oscylowały wokół „instynktu społecznego"11. Leder porównuje niszczycielskie zjawiska społeczne, wojny i katastrofy $X X$ wieku do tzw. procesów regresywnych, ponieważ dotyczą one określonego społecznego i cywilizacyjnego (również kulturowego) stanu upadku i uwstecznienia. Właśnie w tym czasie wprowadzono „higienę rasy”, a pojmanego członka społeczności pigmejskiej Mbuti Ota Benga, uprowadzonego przez handlarzy niewolników, wykupił Amerykanin Samuel Philips Verner, który następnie wystawił go na międzynarodowej wystawie w St. Louis w Luizjanie. Następnie Benga „zamieszkał” razem z małpami w Zoo, na skutek czego popełnił samobójstwo w $1916 \mathrm{roku}^{12}$. Hitleryzm wraz ze swoją ideologią czystości rasy, potwornym deprecjonowaniem człowieka, pozbawieniem życia i godności dużej części ludzkości, odwoływał się - zdaniem francuskiego filozofa Emmanuela Levinasa - do najbardziej pierwotnych emocji i zachowań. Alfred Rosenberg autor Mitu dwudziestego wie$k u$ sam był ochotnikiem do oddziałów Freikorps, które nawiązywały do konspiracyjno-apokaliptycznego antysemityzmu ${ }^{13}$. Warto podkreślić, że podczas II wojny światowej zaspokajano żądze przedstawicieli niemieckiej profesury, dostarczano bowiem ciała katedrom antropologii (wiek XX charakteryzował się narcystycznymi fantazmatami).

Również Wielka Wojna (1914-1918) była związana z ekonomiczną inflacją i bezrobociem. Utrata miejsca upodmiotowienia w konsekwencji doprowadziła ludzkość do aktów regresyjnych. W tamtych czasach dominowała niemiecka irracjonalność, bezmyślne działania, zanik indywidualnego procesu myślenia, a zwłaszcza obojętność i lekceważenie

\footnotetext{
9 Ibidem, s. 59.

10 Ibidem, s. 66.

11 Ibidem, s. 101.

12 Ibidem, s. 105.

13 Ibidem, s. 108.
} 
głosu sumienia ${ }^{14}$. Bezrobocie doprowadziło do tego, że człowiek zaczął być niedostrzegalny dla innych ludzi, ale również dla samego siebie, co spowodowało grozę masakry, unicestwienia, pozbawienia człowieka podstawowych praw do samostanowienia i poczucia bezpieczeństwa. Możliwości fizycznego unicestwienia stały się faktem realnie istniejącym. Nawiązując do myśli niemieckiego filozofa politycznego Carla Schmitta: to, co jest dla określonego człowieka wrogie, znajduje się na zewnątrz moich stosunków społecznych, ja natomiast pragnę obrony przed wrogami, przed tymi, którzy chcą naruszyć moją zabezpieczoną przestrzeń wewnętrzną zapewniającą mi spokój i poczucie stabilizacji ${ }^{15}$.

W podrozdziale zatytułowanym Twarz, morda, pysk Leder zwraca uwagę na aspekt językowy przeżycia grozy obozów koncentracyjnych. W pewnym sensie język stał się konstruktorem doświadczeń, wypowiadał to, co wydawało się niewypowiadalne bądź też wzbudzało niechęć do nadawania znaczeń. Przestrzeń społeczną owładnęła niechęć do tego, co nie jest jednoznaczne. Adolf Eichmann nieustannie bronił samego siebie, własnego umiłowania do porządku, charakteryzowało go skrajne posłuszeństwo wobec prawa i obowiązków. Na drugiego człowieka był jednak ślepy i nie dostrzegał Twarzy Innego, wzywającej do odpowiedzi i zaangażowania ${ }^{16}$.

Słoweński filozof Slavoj Žižek zaangażowanie Martina Heideggera $\mathrm{w}$ pracę akademicką w czasach nazistowskiej opresji opisał za pomocą psychoanalitycznego pojęcia rozegranie w działaniu. Wyrażenie to stanowiło zachowanie pełne narodowosocjalistycznych znaczeń. Zdaniem Heideggera słowo Nichtigkeit odnosi się do charakteru, „nie, odwołuje się do „marności”, „nieważności”, „błahości” i „znikomości”, natomiast ludzkość definiowana jest przez kategorię „winien”17. W momencie trwania Wielkiej Wojny, jak również zaistnienia działań zbrojnych drugiej wojny światowej, możemy mieć do czynienia ze zjawiskiem wyparowania podmiotu mówienia. Język został owładnięty przez samego siebie, duchowo-dziejowe Dasein. Podmioty odpowiedzialności moralnej przestały istnieć, wyparowały, a moralność została rozproszona. Inny człowiek został zakwestionowany i pozbawiony podmiotowości. Już w 1942 roku, po Konferencji w Wannsee, której podstawowym tematem było ostateczne rozwiązanie kwestii żydowskiej, można było przypuszczać, że niezależnie od filozoficznej interpretacji tego odczłowieczonego wydarzenia wyeliminowano wszelką zasadność odpowiedzialności moralnej ${ }^{18}$. Ludzie jako podmioty nazna-

14 Ibidem, s. 121.

15 Ibidem, s. 134.

16 Ibidem, s. 157.

17 Ibidem, s. 175.

18 Ibidem, s. 176. 
czone odpowiedzialnością moralną pozostali rozpuszczeni i niedostrzeżeni. Retoryka stosowana przez oprawców odzwierciedla moment odebrania humanitarnych cech śmierci: osoby zabite odzwierciedla "figuranten", "szmatesy", "fabrykowanie trupów". Muzułman w ujęciu Giorgio Agambena to postać z pogranicza. Nie można na niego patrzeć, obserwować go, patrzący mógłby bowiem zostać sparaliżowany nie tylko mentalnie i etycznie, ale także estetycznie. Podmiot etyczny stał się skamieniały, odporny na każdy rodzaj wezwania moralnego.

Gdy esesman ujrzał czarną plamę, rozlewającą się wokół trepów muzułmana, dostał szału. Rzucił się wprzód, kopiąc w jamę brzuszna, a potem wywróconego i leżącego we własnych odchodach kopał w głowę i klatkę piersiową. Muzułman nie bronił się. Skurczony po pierwszym kopnięciu, skonał po kilkunastu następnych kopnięciach ${ }^{19}$.

Leder, odwołując się do Žižka i jego wspomnień tekstu Breta W. Davisa Heidegger and the Will, stwierdza, że uprzedmiotowienie Innego, poniżenie jego godności, zdeptanie człowieczeństwa ujawniło diaboliczną rozkosz, przyjemność płynącą z sadystycznej depersonalizacji i intencjonalnego zadawania cierpień. Pragnienie poniżania, upodlania to równocześnie źródło wciąż nawracającego w s ty d u ${ }^{20}$. Tony Judt jako Brytyjczyk pochodzenia żydowskiego wychodzi z założenia, że wydarzenia traumatyczne, które dotknęły XX stulecie nie do końca powinny być dla potomności i przyszłości nauczycielka, nie chcąc tym samym, by tego typu skrajna destrukcja i szaleństwo kształtowały świadomość i wrażliwość. Uważa, że trzeźwy ogląd rzeczywistości i dystans jest istotniejszy od bezpośredniości pamięci ${ }^{21}$.

Autor recenzowanej publikacji sądzi, że dwudziestowieczna zagłada została zaprojektowana już w Kartezjańskiej Rozprawie o metodzie. Dominacja myślenia o charakterze racjonalnym i celowym miała właśnie doprowadzić do unicestwienia ${ }^{22}$. Mamy tutaj do czynienia z zamachem na istnienie, jedna społeczność dąży do unicestwienia innej. Zderzamy się ze „stanem wyjątkowym myślenia”, ponieważ przekroczony zostaje horyzont, który reprezentuje hu manizm. Ludobójstwo stało się faktem. Leder zauważa, że w refleksji Gerschoma Scholema mamy do czynienia z pewnym dramatem miłosnym, ponieważ istotne są występujące namiętności. Najważniejsze są gesty przesycone emocjami, spojrzenia,

19 Relacja J. Mostowskiego. Z. Ryn, S. Kłodziński, Na granicy życia i śmierci. Studium obozowego muzułmaństwa, s. 55; cyt. za: G. Agamben, Co zostaje z Auschwitz. Archiwum $i$ świadek, s. 42, w: A. Leder, Rysa na tafli. Teoria w polu psychoanalitycznym, s. 187.

20 A. Leder, Rysa na tafli. Teoria w polu psychoanalitycznym, s. 189-191.

21 T. Judt, Powojnie. Historia Europy po roku 1945, s. 914, w: A. Leder, Rysa na tafli. Teoria w polu psychoanalitycznym, s. 207.

22 A. Leder, Rysa na tafli. Teoria w polu psychoanalitycznym, s. 247. 
zbliżenia, wzgardy i urazy. Dramaty pełne namiętności, gdyż klęski miłosne zawieszone są poza horyzontem historycznym ${ }^{23}$.

Eichmann wcielił się w fałszywą rolę Richarda Klementa, zresztą takich „Klementów” było wielu, a chcieli oni wymazać swą zbrodniczą tożsamość za cenę tej nowszej, nieskalanej, lecz przede wszystkim fałszywej. Eichmann zniknął, przywdziewając mroczną maskę nieistniejącej tożsamości. Żydzi ze słabym przekonaniem prowadzili poszukiwania, albowiem robili wszystko, by nie spostrzegać samych siebie przez pryzmat ofiar. Można w tym momencie skorzystać z pojęcia Freuda, gdyż Żydzi nie chcieli powrotu tego, co zostało już wyparte, nie czuli się na to gotowi ${ }^{24}$. Warto zaznaczyć, że każda forma odpowiedzialności i zbrodni możliwa jest wyłącznie tam, gdzie mamy do czynienia z intencjonalnością, złą wolą. Leder sądzi, że działalność sprawcza Eichmanna nie posiada cech czysto podmiotowych. Był on podmiotem czy maszyną? Był człowiekiem pozbawionym intencji, dlatego można go lokować gdzieś pomiędzy podmiotem a maszyną ${ }^{25}$. Zachodni myśliciele, zaczynając od Adorna, a kończąc na Agambenie, stanowią rodzaj oświeceniowo-racjonalistycznego humanizmu, który jest nieprzerwanie sprzężony $\mathrm{z}$ traumą powiązaną z doświadczeniem Zagłady ${ }^{26}$.

Andrzej Leder, analizując fenomen XX-wiecznych tragedii wojennych, wprowadza kategorię traumy i melancholii. Trauma z jednej strony może zniewolić człowieka, z drugiej natomiast wywołuje traumatyczne przeżycia i grozę istnienia, ponieważ skrajne oraz przeciwstawne emocje czy obrazy powodują stan zastygnięcia i niewiary. Holenderski historiozof Frank Ankersmit uważa, że „generalnie trauma może być postrzegana jako psychologiczny odpowiednik wzniosłości, a wzniosłość - jako filozoficzny odpowiednik traumy" ${ }^{27}$. Obiekt podlegający doświadczeniu, który może być ujmowany przedmiotowo, nie uobecnia się, nie jest reprezentowany. Trauma nie może być reprezentowana, gdyż spotykamy się z reprezentacjami procesów opracowania aktów traumatycznych. Traumatyczny widok może w konsekwencji doprowadzić do wstrząsu, bo dosięga rdzenia i centrum ludzkiej podmiotowości, stanowi etyczną relację $\mathrm{w}$ stosunku do Innego ${ }^{28}$. Praca $\mathrm{z}$ traumą jest spotkaniem $\mathrm{z}$ realnym, jest to etyczny wymiar doświad-

${ }^{23}$ G. Scholem, Żydzi i Niemcy, s. 76, w: A. Leder, Rysa na tafli. Teoria w polu psychoanalitycznym, s. 248.

24 A. Leder, Rysa na tafli. Teoria w polu psychoanalitycznym, s. 258.

25 Ibidem, s. 265.

26 Ibidem, s. 300.

27 F. Ankersmit, Wzniosłe odłaczenie się od przeszłości albo jak byćlstać się tym, kim się już nie jest, w: Narracja, reprezentacja, doświadczenie. Studia z teorii historiografii, s. 347, w: A. Leder, Rysa na tafli. Teoria w polu psychoanalitycznym, s. 314.

28 Ibidem, s. 326. 
czania ${ }^{29}$ " „Trauma narusza spoistość etyczną, jest doświadczeniem, w którym przerwana zostaje nie tyle nasza zdolność reprezentowania świata, ile poczucie etycznej „sobości” ${ }^{30}$. Przeszłość nie jest już postrzegana jako powód do bycia dumnym, jej konsekwencje jawią się jako katastroficzne $^{31}$.

Aleksandra Kondrat Uniwersytet Mikołaja Kopernika, Toruń e-mail: moskwa.ros@gmail.com

29 Ibidem, s. 331.

30 Ibidem, s. 327.

31 Ibidem, s. 343. 